\title{
PENDIDIKAN AGAMA ISLAM DAN INDUSTRI 4.0
}

\author{
Dra. Ifham Choli, MM, M.Pd \\ Ifhamcholi.fai@uia.ac.id
}

(Dosen Universitas Islam As-Syafi'iyah)

\begin{abstract}
The development of industry 4.0 is a challenge for the world of education, including Islamic education. Teachers inevitably have to be demanded to face more complex challenges. There are many complex challenges of the industrial revolution 4.0 in the field of Islamic education, including: First, the teacher-student relationship and the kiai-santri are human relations that have strategic values in Islam. Teacher competence is not enough if only applying the learning or teaching process like tens or even hundreds of years ago, where the teacher was present to be absent, enter class, question and answer and discussion. Educators who are expected to have the ability in ICT are urgently needed starting from early childhood educators, to educators in tertiary institutions. It is hoped that educators will have skills in ICT so that they will be able to assist children in utilizing existing technology and be able to provide educational facilities for the whole community. In the industrial era 4.0, learning is expected to provide more opportunities for students to be creative, solve problems, optimize literacy and numeracy skills, collaboration, and critical thinking. In moving towards the era of globalization, Indonesia must carry out reforms in the education process, with the pressure to create a more comprehensive, flexible education system, so that graduates can function effectively in the life of a democratic global society. For this reason, education must be designed in such a way as to enable students to develop their natural and creative potential in an atmosphere of freedom, togetherness, and responsibility.
\end{abstract}

Keywords: Education, Religion, Islam, Industry 4.0

\begin{abstract}
Abstrak
Perkembangan industri 4.0 menjadi tantangan bagi dunia pendidikan, termasuk pendidikan Islam. Para guru mau tidak mau harus dituntut untuk menghadapi tantangan yang lebih kompleks. Ada banyak kompleksitas tantangan revolusi industri 4.0 di bidang pendidikan Islam, diantaranya: Pertama, relasi guru-murid maupun kiai-santri adalah hubungan manusia yang memiliki nilai strategis dalam Islam. Kompetensi guru tidak cukup bila hanya menerapkan proses belajar atau mengajar seperti puluhan bahkan ratusan tahun yang lalu, di mana guru hadir untuk absen, masuk kelas, tanya jawab dan diskusi. Pendidik yang diharapkan memiliki kemampuan dalam ICT sangat dibutuhkan mulai dari pendidik anak usia dini, hingga pendidik di perguruan tinggi. Besar harapan agar pendidik memiliki keterampilan dalam ICT sehingga akan mampu pula mendampingi anak dalam memanfaatkan teknologi yang ada dan mampu memberikan kemudahan pendidikan untuk seluruh masyarakat. Pada era industri 4.0., pembelajaran diharapkan lebih banyak memberikan kesempatan pada siswa untuk kreatif,
\end{abstract}


memecahkan masalah, mengoptimalkan kemampuan literasi dan numeracy, kolaborasi, dan berpikir kritis. Dalam menuju era globalisasi, Indonesia harus melakukan reformasi dalam proses pendidikan, dengan tekanan menciptakan sistem pendidikan yang lebih komprehensif, dan fleksibel, sehingga para lulusan dapat berfungsi secara efektif dalam kehidupan masyarakat global demokratis. Untuk itu, pendidikan harus dirancang sedemikian rupa yang memungkinkan para peserta didik mengembangkan potensi yang dimiliki secara alami dan kreatif dalam suasana penuh kebebasan, kebersamaan, dan tanggung jawab.

Kata Kunci: Pendidikan, Agama, Islam, Industri 4.0

\section{A. Pendahuluan}

Esensi dari pendidikan adalah adanya proses transfer nilai, pengetahuan dan keterampilan dari generasi tua kepada generasi muda agar generasi muda mampu hidup. Oleh karena itu, ketika kita menyebut pendidikan Islam maka akan mencakup dua hal: mendidik siswa untuk berperilaku sesuai dengan nilai-nilai atau akhlak Islam dan mendidik siswa-siswi untuk mempelajari materi ajaran Islam subjek berupa pengetahuan tentang ajaran Islam. ${ }^{1}$ Dalam ajaran Islam ditegaskan bahwa pendidikan hendaknya serba meliputi. Sebagaimana yang terungkap dalam Q.S Luqman: 1-34 yang intinya pendidikan hendaknya memberi penyadaran potensi fitrah keagamaan, menumbuhkan, mengelola dan membentuk wawasan, akhlak serta tingkah laku yang sesuai dengan ajaran Islam, menggerakkan dan menyadarkan manusia untuk senantiasa beramal saleh dalam rangka beribadah kepada Allah.

Konformisme atau cepat merasa puas dengan keadaan yang ada menjadi kendala mendasar dalam mengembangkan kurikulum pendidikan Islam. Lembaga pendidikan dasar dan menengah masih menggunakan model kurikulum lama dengan mengandalkan pendidikan dasar agama sebagai bekal mengajarkan pendidikan agama lebih lanjut kepada masyarakat. Pembahasan yang diajarkan pun masih banyak menekankan aspek normatif dengan (mohon maaf) mengesampingkan aspek transformatif dalam konteks sosio-kultural masyarakat kita. Jangan kaget bila ada sekelompok ikhwan yang sudah merasa cukup hanya dengan mengkaji ilmu-ilmu (kontemporer) yang sebenernya sama pentingnya. ${ }^{2}$

\footnotetext{
${ }^{1}$ Malik Fajar, Holistik Pemikiran Pendidikan, Jakarta, Raja Grafindo Persada, 2005,hal.131.

${ }^{2}$ Ali Mahsun (dalam Dimas), digital.library.ump.ac.id/254/4/9
} 
Ada beberapa hal yang bisa dilakukan bagi peningkatan sistem pendidikan Islam dan kecenderungan masa depan global. ${ }^{3}$ Pertama, umat Islam harus mampu memanfaatkan sarana teknologi sebagai alat perjuangan (jihad) nya. Artinya, sarana teknologi perlu dijadikan sebagai alat perjuangan umat Islam dalam meningkatkan kualitas pendidikan dan bukan sebaliknya sebagai penghalang bagi kreativitas berpikir dan berbuat bagi perubahan untuk kemajuan. Kedua, umat Islam harus secara terus menerus meningkatkan SDM yang berkualitas Iptek dan Imtaq secara bersamaan, atau peningkatan diri ke arah kekokohan spiritual, moral, dan intelektual. Ketiga, proses modernisasi adalah sesuatu yang meniscayakan bagi perombakan sistem pendidikan Islam, mulai dari paradigma, konsep kerangka kerja, dan evaluasi. Pada dasarnya semua civitas akademika sistem pendidikan Islam harus memiliki sense of development ke arah yang lebih baik sehingga lembaga pendidikan yang ada menjadi laboratorium masa depan yang harmoni.

Revolusi Industri 4.0 merupakan konsep yang pertama kali diperkenalkan oleh ekonom asal Jerman, Profesor Klaus Schwab dalm bukunya yang berjudul "The Fourth Industrial Revolution". Klaus mengungkapkan empat tahap revolusi industri yang setiap tahapannya dapat mengubah hidup dan cara kerja manusia. Revolusi industry 4.0 merupakan tahap terakhir dalam konsep ini setelah tahapan pada abad ke-18, ke-20, dan awal $1970{ }^{4}$

Sebelum datangnya revolusi industri 4.0, pembangunan dilakukan secara manual dengan menggunakan tenaga otot yang dilakukan oleh manusia dan juga binatang seperti dalam sektor pertanian dan peperangan. Di Jerman tenaga manusia semakin berkurang sehingga digantikan dengan mesin. Berbeda dengan di Indonesia, apabila tidak menggunakan industri 4.0 maka produk kita tidak bisa bersaing dengan produk luar dan akan tergilas dengan pasar global.

Perkembangan industri 4.0 menjadi tantangan bagi dunia pendidikan, termasuk pendidikan Islam. Para guru mau tidak mau harus dituntut untuk menghadapi tantangan yang lebih kompleks. Ada banyak kompleksitas tantangan revolusi industri 4.0 di bidang pendidikan Islam, diantaranya relasi guru-murid maupun kiai-santri adalah hubungan manusia yang memiliki nilai strategis dalam Islam.

\footnotetext{
${ }^{3}$ Abdus Syakur, Revitalisasi Teknologi Pendidikan Islam. Tadris Volume 11 Nomor 2, Desember 2016

${ }^{4}$ Saniah, qureta.com, 2019
} 


\section{B. Pembahasan}

\section{Pengertian Pendidikan Agama Islam dan Industri 4.0}

Pendidikan agama Islam adalah pendidikan melalui ajaran-ajaran agama Islam, yaitu berupa bimbingan dan asuhan terhadap anak didik agar nantinya setelah selesai dari pendidikan ia dapat memahami, menghayati dan mengamalkan ajaran-ajaran agama Islam yang telah diyakininya secara menyeluruh, serta menjadikan ajaran agama Islam itu sebagai suatu pandangan hidupnya demi keselamatan hidup di dunia maupun di akhirat. ${ }^{5}$

Menurut H.M. Arifin, pendidikan Islam berarti sistem pendidikan yang dapat memberikan kemampuan seseorang untuk memimpin kehidupannya sesuai dengan cita-cita dan nilai-nilai Islam yang telah menjiwai dan mewarnai corak kepribadiannya. Dengan kata lain, manusia yang mendapatkan pendidikan Islam harus mampu hidup di dalam kedamaian dan kesejahteraan sebagaimana diharapkan oleh cita-cita Islam. Dengan demikian pengertian pendidikan Islam adalah suatu sistem kependidikan yang mencakup seluruh aspek kehidupan yang dibutuhkan oleh hamba Alloh, sebagaimana Islam telah menjadi pedoman bagi seluruh aspek kehidupan manusia, baik duniawi maupun ukhrawi. ${ }^{6}$

Sedangkan pendidikan agama Islam menurut M. Ainur Rosyid adalah proses mengubah tingkah laku individu pada kehidupan pribadi, alam sekitar, dan masyarakatnya dengan cara pengajaran sebagai suatu aktivitas asasi dan sebagai profesi diantara profesi-profesi asasi dalam masyarakat. $^{7}$

Revolusi industri terdiri dari dua (2) kata yaitu revolusi dan industri. Revolusi dalam Kamus Besar Bahasa Indonesia (KBBI), berarti perubahan yang bersifat sangat cepat, sedangkan pengertian industri adalah usaha pelaksanaan proses produksi. Sehingga jika dua (2) kata tersebut dipadukan bermakna suatu perubahan dalam proses produksi yang berlangsung cepat. Perubahan

\footnotetext{
${ }^{5}$ Abdul Rahman Shaleh, Pendidikan Agama \& Membangun Watak Bangsa, jakarta, PT RajaGrafindo Persada, 2005, hal. 6

${ }^{6}$ Arifin, 2014, Ilmu Pendidikan Islam, Jakarta, Bumi Aksara, hal. 7

${ }^{7}$ Ainur Rosyid, 2017, Hadits-hadits Tarbawi, Yogyakarta, Diva Press, hal. 13
} 
cepat ini tidak hanya bertujuan memperbanyak barang yang diproduksi (kuantitas), namun juga meningkatkan mutu hasil produksi (kualitas). ${ }^{8}$

Revolusi Industri adalah perubahan besar dan radikal terhadap cara manusia memproduksi barang. Perubahan besar ini tercatat sudah terjadi tiga kali, dan saat ini kita sedang mengalami revolusi industri yang keempat. ${ }^{9}$

Istilah Revolusi industri diperkenalkan oleh Friedrich Engels dan Louis Anguste Blanqui di pertengahan abad ke-19. Revolusi industri ini pun sedang berjalan dari masa ke masa. Dekade terakhir ini sudah dapat disebut memasuki fase keempat 4.0. Perubahan fase ke fase memberi perbedaan artikulatif pada sisi kegunaannya. Fase pertama (1.0) bertempuh pada penemuan mesin yang menitikberatkan (stressing ) pada mekanisasi produksi. Fase kedua (2.0) sudah beranjak pada etape produksi massal yang terintegrasi dengan quality control dan standarisasi. Fase ketiga (3.0) memasuki tahapan keseragaman secara massal yang bertumpu pada integrasi komputerisasi. Fase keempat (4.0) telah menghadirkan digitalisasi dan otomatisasi perpaduan internet dengan manufaktur. ${ }^{10}$

\section{Era Digital dan Inovasi Pembelajaran Berbasis Teknologi}

Perkembangan dunia digital tak lagi sekedar memengaruhi, bahkan mengubah perilaku dan kebiasaan masyarakat. Digitalisasi kehidupan yang semakin berkembang pesat ke depan inilah yang mesti dibaca dunia pendidikan sehingga bisa membekali anak-anak kita kecakapankecakapan penting untuk menghadapinya. Pendidikan saat ini mesti membekali anak kecakapan hidup sepuluh hingga dua puluh tahun mendatang. Artinya, dunia pendidikan mesti bisa memprediksi dan menyiapkan kecakapan-kecakapan apa yang mesti dimiliki oleh anak untuk hidup di masa depan. Di titik inilah, pendidikan mesti bisa menyesuaikan diri dengan perkembangan pesat di bidang teknologi informasi dan komunikasi dengan mulai membangun sistem pendidikan atau pembelajaran di era digital. ${ }^{11}$.

Revolusi digital didasari perkembangan komputer elektronik digital, yaitu komputer pribadi, dan khususnya mikroprosesor dengan kinerjanya yang terus meningkat, yang

\footnotetext{
${ }^{8}$ Sigit Priatmoko, E-jurnalunisda.ac.id/index.php/ta'lim/article/view/948/1066, Vol.1, No.2, 2018, hal. 229

${ }^{9}$ https://www.zenius.net/blog. revolusi industri

${ }^{10}$ Hendra Suwardana, Revolusi Industri, 4.0, Berbasis Revolusi mental, JATI UNIK, Vol. 1, No.2, 2017, hal. 102

${ }^{11}$ https://www.viva.co.id>vstory
} 
memungkinkan teknologi komputer untuk tertanam ke berbagai objek besar dari kamera ke pemutar musik pribadi. Sama pentingnya adalah pengembangan teknologi transmisi termasuk jaringan komputering, Internet dan penyiaran digital. Ponsel 3G dan 4G, yang tumbuh pesat penetrasi sosial pada tahun 2000, juga memainkan peran yang sangat besar dalam revolusi digital karena mereka secara bersamaan memberikan hiburan di manamana, komunikasi, dan konektivitas online. Dalam konteks kondisi pembelajaran yang menyenangkan, atau biasa dikenal dengan edutainment, Davies ,2011 (dalam Dimas) menegaskan bahwa suatu kegiatan pembelajaran tidak selalu menjamin peserta didik akan dapat belajar. Hal ini menunjukkkan bahwa sebaik apapun seorang guru dalam merancang dan mendesain suatu program pembelajaran, kiranya tidak akan dapat secara optimal mewujudkan ketercapaian kompetensi yang diharapkan apabila tidak didukung oleh pemilihan sekaligus penggunaan metode secara tepat. Untuk itu peranan masyarakat digital di era revolusi industri 4.0 ini menjadi tantangan bagi membangun pendidikan berbasis teknologi informasi yang mampu menjawab tantangan kebutuhan masyarakat era revolusi industri 4.0 ini. Tantangan Pendidikan di Era Revolusi Industri 4.0. ini. $^{12}$

\section{Tantangan Pendidikan di Era Revolusi Industri 4.0}

Tantangan pada dunia pendidikan dalam menghadapi industri 4.0 adalah penanaman nilainilai pendidikan yang perlu dikembangkan. ${ }^{13}$ Menurut Guilford, 1985 (dalam Samrin) penerapan dari pendidikan nilai yang dikembangkan adalah: 1) anak dididik dan dilatih dengan cara bekerja sambil belajar. Kecerdasan berfikir anak dikembangkan dengan seluas-luasnya; 2) memupuk kepribadian anak dengan kepribadian Indonesia sehingga menjadi pribadi yang dinamis, percaya diri, berani, bertanggung jawab dan mandiri; 3) pelajaran tidak hanya diberikan pada jam pelajaran saja, tetapi juga dalam setiap kesempatan di luar jam sekolah; dan 4) contoh perbuatan baik diterapkan karena lebih berhasil dalam membina watak yang baik . hal inilah yang membedakan manusia dengan mesin di era globalisasi industri ke 4.

Kirschenbaum, 1992 (dalam Nur Hidayat) menyatakan bahwa pendidikan nilai pada dasarnya lebih ditujukan untuk memperbaiki moral bangsa. Pendidikan nilai mengajarkan

\footnotetext{
12 Dimas, Prosiding Seminar Nasional Prodi PAI UMP Tahun 2019, ISBN: 978-602-6697-31-8, hal. 106

${ }^{13}$ Samrin. Pendidikan Islam di Era Globalisasi (Peluang \& Tantangan). Shoutut Tarbiyah, Ed.ke-36 Th. XXIII, Mei 2017. Hal.4-5.
} 
generasi muda tentang value dan moral yang seharusnya dimiliki. Pendidikan nilai ditujukan untuk mencegah antara lain meningkatnya kasus kejahatan, degradasi moral dan penggunaan obat-obatan terlarang oleh generasi muda. Melalui pembelajaran berbasis nilai diharapkan siswa dapat menentukan nilai baik dan buruk dalam kehidupan sehingga dapat memilih nilai yang baik untuk peningkatan kualitas hidupnya di dalam masyarakat. Tapi pada kenyataanya, semakin pesatnya arus teknologi justru siswa- siswa semakin terlena dan memiliki sikap yang enggan bertanggung jawab, degradasi moral dan meningkatnya kasus kejahatan dikalangan siswa. Dengan adanya aplikasi media sosial yang mempermudah dalam mengakses informasi dan komunikasi mengakibatkan menjamurnya kejahatan di media online. Hal ini dikarenakan kurangnya pendidikan nilai dan tantangan bagi pendidik untuk menguatkan karakter moral siswa agar tidak terjerumus dan terlena dengan pesatnya teknologi industri 4.0. ${ }^{14}$

Salah satu substansi dari pendidikan Agama Islam adalah pendidikan moral merupakan suatu upaya membantu peserta didik dalam menuju satu tahap perkembangan sesuai dengan kesiapan mereka. Dilema-dilema moral sudah cukup untuk menggerakkan perkembangan moral untuk membantu peserta didik dalam menyikapi isi nilai. Untuk meningkatkan keberhasilan program pendidikan moral, maka upaya pendidikan tersebut haruslah dilakukan dalam satu just school environment. Nilai-nilai yang mulai tergerus akibat tranformasi industri 4 adalah sebagai berikut :

1. Nilai Kultural.

Nilai kultural adalah nilai yang berhubungan dengan budaya, karakteristik lingkungan sosial dan masyarakat. Pendidikan dapat menolong siswa untuk melihat nilai-nilai kultural sosial secara sistematis dengan cara mengembangkan keseimbangan yang sehat antara sikap terbuka (openness) dan tidak mudah percaya (skepticism).

\section{Nilai Yuridis Formal}

Nilai Yuridis formal adalah nilai yang berkaitan dengan aspek politik, hukum dan ideologi. Nilai sosial politik suatu bahan ajar merupakan kandungan nilai yang dapat memberikan

\footnotetext{
${ }^{14}$ Nur Hidayat, Peran dan Tantagan Pendidikan Agama Islam Di Era Global. Jurnal el-Tarbawi. Volume XIII, No 2, 2015, hal.135-137
} 
petunjuk kepada manusia untuk bersikap dan berperilaku sosial yang baik ataupun berpolitik yang baik dalam kehidupannya.

3. Nilai Religius

Mempertahankan nilai-nilai tersebut merupakan tantangan terberat dalam menghadapi revolusi industri 4.0. Perkembagan jaman menuntut manusia lebih kreatif karena pada dasarnya jaman tidak bisa dilawan. Revolusi industri 4.0. banyak menggunakan jasa mesin dibandingkan manusia. Tetapi ada hal penting yang membedakan mesin dengan manusia yaitu dari segi nilai kemanusiaan yang tidak dimiliki oleh mesin. Penanaman nilai inilah yang perlu diperkuat untuk mengangkat harkat dan martabat dunia pendidikan. ${ }^{15}$

Pendidikan Islam saat ini sedang ditantang kontribusinya terhadap pembentukan peradaban dan budaya modern yang relevan dengan perkembangan ilmu pengetahuan, teknologi, dan seni (iptek). Pada dimensi ini, pendidikan Islam mengalami kemunduran fungsi (degrasi fungsional) karena pendidikan Islam lebih berorientasi pada aspek moral spiritual. Terdapat banyak pendapat yang mengatakan bahwa pendidikan Islam tidak terlalu fokus memprioritaskan aspek yang bersifat praktis dan pragmatis, seperti penguasaan teknologi. Akibatnya, pendidikan Islam tidak mampu bersaing pada level kebudayaan di tingkat global. ${ }^{16}$

\section{Pendidikan Agama Islam di Era Revolusi Industri 4}

Memasuki era industri 4.0, dunia pendidikan diminta untuk membekali masyarakat dengan nilai-nilai luhur. Salah satunya nilai keislaman. Mengikuti arus industri 4.0 tidak bisa dijadikan penghalang dalam bersikap luhur. Dengan adanya teknologi yang bervariasi, seseorang justru memiliki banyak pilihan untuk menebar hal positif, manfaatkan teknologi itu untuk mengajarkan orang lain dalam menghayati nilai-nilai yang terkandung dalam al-Quran. ${ }^{17}$

Adanya tantangan dalam bentuk sebuah permasalahan sebisa mungkin diiringi dengan solusi untuk mengatasi permasalahan yang ada. Dunia pendidikan saat ini mulai disibukkan untuk menyiapkan generasi yang mampu bertahan dalam kompetisi di era industri 4.0. Dalam menghadapi era revolusi industri 4 beberapa hal yang harus dipersiapkan diantaranya: a)

\footnotetext{
${ }^{15}$ Akhmad Syahri, Spirit Islam dalam Teknologi Pendidikan Di Era Revolusi Industri 4.0 Attarbiyah, Volume 28, 2018 hal. 62

${ }^{16}$ Mawardi Pewangi, Journal.unismuh.ac.id/index.php/tarbawi/aeticle/view/347/320, 2019

17 https://uin-malang.ac.id/r/181101/jangan-tinggalkan nilai-islam-di era-industri 4,0
} 
persiapan sistem pembelajaran yang lebih inovatif . untuk menghasilkan lulusan yang kompetitif dan terampil terutama dalam aspek data literacy, technological literacy and human literacy. b) Rekonstruksi kebijakan kelembagaan pendidikan yang adaptif dan responsif terhadap revolusi industri 4.0 dalam mengembangkan transdisiplin ilmu dan program studi yang dibutuhkan. c) Persiapan sumber daya manusia yang responsive, adaptif dan handal untuk menghadapi revolusi industri 4. d) Peremajaan sarana prasarana dan pembangunan infrastruktur pendidikan, riset, dan inovasi juga perlu dilakukan untuk menopang kualitas pendidikan, riset, dan inovasi. ${ }^{18}$ Berdasarkan pendapat tersebut, dalam pembahasan ini solusi dari tantangan pendidikan di era revolusi industri 4 sebagai berikut.

1. Kesesuaian kurikulum dan kebijakan pendidikan di Indonesia.

Kesesuian kurikulum dan kebijakan pendidikan dapat dilihat salah satunya melalui kompetensi yang dimiliki oleh lulusan pendidikan. Menengok pendidikan di Indonesia saat ini masih diselimuti dengan berbagai macam problematika yang kurang mendukung siswa untuk dapat bertahan di era indutrsi 4 tentu menjadi kajian yang harus ditemukan solusinya. Adapun tawaran solusi sekaligus saran pada beberapa pihak terkait dengan dunia pendidikan Agama Islam, di antaranya: a) Tidak menjadikan kurikulum hanya sebagai dokumen tertulis yang tidak diterapkan dengan baik. Hal ini sering kali terjadi, ketika kurikulum sudah tersusun sedemikian baik, namun dalam pelaksaanaan justru tidak sesuai dengan tujuan pembelajaran yang ada dalam kurikulum. b) Mewujudkan pendidikan agama Islam yang mengarah pada kemampuan Kognitif, Afektif dan Psikomotorik c) Melakukan evaluasi kebijakan dan atau kurikulum lembaga pendidikan Islam di Indonesia yang berdasarkan pada orientasi kebutuhan pendidikan, bukan politisasi.

\section{Kesiapan SDM dalam Pemanfaatan ICT}

Saat ini, menyiapkan semua sistem pendidikan yang ditujukan untuk memaksimalkan kemampuan yang dimiliki generasi milinieal tentunya tidak bisa lepas dengan peralatan teknologi terkini. Oleh karena itu solusi dalam bidang pendidikan yang berkaitan dengan tantangan di era revolusi industri 4 akan selalu berkaitan dengan kesiapan sumber daya

\footnotetext{
${ }^{18}$ Khusnan Arif, Teknologi Pembelajaran Pendidikan Agama Islam dalam Paradigma Konstruktivistik, Jurnal Fikroh, Vol.4 no 2, Januari 2011
} 
manusia dan sarana prasarana sebagai pengguna ICT. Faktanya di Indonesia saat ini, tidak semua pendidik mampu dalam memanfaatkan teknologi. Hasil penelitian menunjukkan $62,15 \%$ guru jarang menggunakan Teknologi Informasi dan Komunikasi dalam pembelajaran; dan 34,95\% guru kurang menguasai Teknologi Informasi dan Komunikasi, sedangkan 10,03\% . Hal tersebut disebabkan oleh kurangnya pengetahuan pendidik, faktor usia, dan masih terikat dengan penggunaan media konvensional. Pemahaman pendidik tentang pentingnya memanfaatkan teknologi dalam pembelajaran juga masih rendah. Hal tersebut tentunya bertolak belakang dengan harapan yang tertuang sebagai solusi dalam menghadapi era industri 4.0. Ditinjau dari permasalahan pendidikan di Indonesia yang memiliki daerah-daerah terpencil dan terisolir, maka minimnya keterampilan pendidik dalam menggunakan ICT justru akan memperburuk permasalahan. ${ }^{19}$

3. Kesiapan SDM dalam mengoptimalkan kemampuan dan karakter siswa

Solusi lain untuk menjawab tantangan pendidikan agama Islam di era industri 4 yaitu dari segi kemampuan dan pembentukkan karakter siswa. Pada era industri 4.0, pembelajaran diharapkan lebih banyak memberikan kesempatan pada siswa untuk kreatif, memecahkan masalah, mengoptimalkan kemampuan literasi dan numeracy, kolaborasi, dan berpikir kritis. ${ }^{20}$ Berdasarkan paparan tersebut, berbagai macam pendekatan, strategi,dan metode yang digunakan pendidik harus dapat memberikan kesempatan pada siswa untuk mengembangkan kemampuan yang diharapkan di era industri 4. Setiap pendidik memiliki pilihan masingmasing yang tentu disesuaikan dengan karakteristik siswanya. Selain kemampuan kognitif siswa, karakter atau pengembangan nilai pada diri siswa juga sangat dibutuhkan. Oleh karena itu, pendidikan di era revolusi industri 4 harus mampu mencetak siswa yang berkarakter sehingga tidak hanya bertahan pada zamannya tetapi juga mampu mengkritisi zaman.

Beberapa langkah untuk mewujudkan siswa yang berkarakter, di antaranya:

1) mengenalkan siswa dengan nilai-nilai yang dimiliki bangsanya melalui pendidikan kewarganegaraan. Pendidikan nilai di lingkungan terdekat anak, khususnya keluarga

\footnotetext{
1919 Asnawan, Pendidikan Islam dan Teknologi Komunikasi, Jurnal falasifa, Vol 1, No 2, September 2010, hal. 94-95 ${ }^{20}$ Aisyah Tidjani, Manajemen Lembaga Pendidikan Islam Menghadapi Tantangan Globalisasi, Jurnal Reflektika, Vol 13, No 1, Januari-Juni 2017
} 
2) Anak dididik dan dilatih dengan cara bekerja sambil belajar.

3) Kecerdasan berfikir anak dikembangkan dengan seluas-luasnya;

4) memupuk kepribadian anak dengan kepribadian Indonesia sehingga menjadi pribadi yang dinamis, percaya diri, berani, bertanggung jawab dan mandiri;

5) pelajaran tidak hanya diberikan pada jam pelajaran saja, tetapi juga dalam setiap kesempatan di luar jam sekolah; dan

6) contoh perbuatan baik diterapkan karena lebih berhasil dalam membina watak yang baik. Adanya keseimbangan antara kemampuan kognitif dan karakter yang dimiliki siswa itulah yang harus dijadikan tujuan dari pendidikan di era sekarang. Dalam hal ini, dibutuhkan kesiapan semua pihak untuk dapat memberi pemahaman, teladan, dan evaluasi dari pembiasaan nilai dalam kehidupan sehari-hari. ${ }^{21}$

Berdasarkan paparan tersebut, solusi dalam segi kesiapan sumber daya manusia dalam dunia pendidikan, khususnya di Indonesia untuk menjawab tantangan pendidikan agama Islam di era industri 4 , dapat diperinci sebagai berikut.

a. Memberikan pemahaman atau pengetahuan kepada seluruh pendidik untuk mampu memanfaatkan ICT dalam pembelajaran, membimbing siswa dalam menggunakan ICT dan mempermudah pelaksanaan pendidikan Islam.

b. Memberikan pelatihan, pendampingan, dan evaluasi secara kontinyu pada pendidik untuk mewujudkan pendidik responsive, handal, dan adaptif

c. Menyiapkan pendidik untuk dapat menciptakan pembelajaran yang inovatif.

d. Memberikan pendidikan kewarganegaraan yang bermakna bagi siswa, sebagai bagian dari pendidikan nilai untuk mewujudkan manusia yang berkarakter.

Revolusi Industri 4.0 tidak hanya mengubah tatanan budaya dan pola kehidupan masyarakat, melainkan juga mendorong munculnya berbagai gagasan-gagasan baru dalam segi keagamaan (religiusitas), spiritualitas, serta nilai-nilai sosial kehidupan. Munculnya gagasan-

\footnotetext{
${ }^{21}$ Iswan dan Herwina, Penguatan Pendidikan Karakter Perspektif Islam dalam Era Millenial I.R 4.0, Prosiding Seminar Nasional Pendidikan Era Revolusi “Membangun Sinergitas dalam Penguatan Pendidikan Karakter pada Era IR 4.0" Universitas Muhammadiyah Jakarta, Indonesia, 24 Maret 2018
} 
gagasan baru yang terkonsepsi dari pendidikan harus dikaji ulang. Islam sebagai agama Rahmatan lil ,alamin (religiusitas) menjadi hal penting yang perlu diperhatikan untuk menanggapi perkembangan zaman. Realitanya pendidikan Islam kurang mendorong munculnya pemikiran yang kritis. Padahal Islam dapat menjawab segala tantangan perubahan zaman, karena pedomannya yang jelas yaitu Al-Qur'an, penyempurna pedoman hidup manusia. Apabila zaman berkembang dengan kekuatan teknologi informasi global, maka banyak sekali peluang yang dapat diambil dalam pendidikan nasional pada umumnya dan pendidikan Islam pada khususnya. Keberadaan Islam menjadi tonggak penting dalam dunia pendidikan itu sendiri dan Islam dapat memasuki semua ranah perkembangan dunia. Islam dapat memunculkan dirinya sebagai sebuah keunggulan di tengah- tengah keanekaragaman global, terutama di dunia pendidikan. Media dan teknologi informasi adalah sarana berbagi untuk mendapatkan informasi baik dan bermanfaat. Kerapkali bilamana tanpa adanya penyeimbangan sisi religiusnya maka informasi-informasi yang beredar akan kurang bernilai. Dapat dilihat dari konten penayangan oleh media informasi sekarang lebih banyak menampakkan hal-hal negatif di dalam iklan, film, serta produk-produk hiburan lainnya. Dalam hal ini pentingnya pengembangan budaya kritis dan religious yang tetap bisa memenuhi kebutuhan hiburan dan selera estetik dalam perkembangan media-media era sekarang. ${ }^{22}$

Untuk menciptakan anak didik yang cerdas, ataupun yang trend kini disebut dengan istilah Generasi Millenial, maka guru harus mampu memotivasi siswanya agar lebih kreatif dalam mengembangkan potensi dan meraih prestasinya. Ada banyak tantangan dalam dunia pendidikan di era industri 4.0 ini, yaitu perubahan cara belajar, pola berpikir juga pola bertindak dari peserta didik dalam mengembangkan inovasi. Untuk itu, sebagai seorang guru dituntut juga memiliki skill dalam menghadapinya. ${ }^{23}$

Menurut Prof. Dede Rosyada 2019 (dalam jurnal Saefudin Zuhri), Pendidikan Agama Islam (PAI) mendapatkan mandat dari Allah sebagai proses penyiapan generasi sekarang dan yang akan datang sebagai generasi terbaik di muka bumi (Ali Imran: 110). Dalam ayat tersebut ditegaskan untuk menjadi umat terbaik harus melakukan tiga hal, senantiasa memerintahkan

\footnotetext{
${ }^{22}$ Mulkhan, Abdul Munir S.U (2002), Nalar Spiritual Pendidikan: Solusi Problem Filosofis Pendidikan Islam, Yogyakarta: PT Tiara Wacana Yogya. 51

${ }^{23}$ Dede Rosyada, lain-padangsidimpuan.ac.id/prof-dr-dede-rosyadama-jadilah-guru-yang-kreatif-dalammenghadapi-era-industri-4-0/
} 
untuk melakukan perbuatan baik, senantiasa mencegah umat Islam melakukan perbuatan buruk, dan senantiasa menjaga serta memperkuat keimanan kepada Allah. ${ }^{24}$

Tujuan Pendidikan Agama Islam adalah:

1. Agar para siswa memahami, menghayati dan mengamalkan ajaran-ajaran agama yang menjadi anutannya.

2. Agar para siswa mampu menyerasikan penguasaan PAI dengan penguasaan dan implementasi sains dan teknologi. Artinya PAI bertujuan, agar para siswa mampu mengintegrasikan sistem keyakinan keagamaannya dalam kehidupan profesi dan sosial para siswa, kelak sesudah mereka menjadi profesional. ${ }^{25}$

Mengenai peran Islam yang dapat dilakukan terhadap perkembangan IPTEK, Nasruddin Hasibuan (dalam Akhmad Syahri) menyampaikan setidaknya terdapat dua hal yang perlu diperhatikan, yaitu:

1. Aqidah Islam harus dijadikan basis segala konsep dan aplikasi IPTEK. Paradigma ini yang harus dikembangkan oleh kaum muslim saat ini. Banyak pendidikan yang berlangsung dan segala kemajuan teknologi pendidikan yang menghindari kebenaran aqidah Islam, layaknya pendidikan berbasis Sekuler. Seperti teori Darwin yang bertolak belakang dengan Aqidah Islam. Meskipun aqidah Islam dijadikan landasan dalam mengembangkan IPTEK, tapi tak selamanya ilmu- ilmu seperti ilmu astronot, ilmu kedokteran, geologi berasal dari ayat-ayat yang ada di Al-Qureean. Melainkan menjadikan Al-Quran dan Hadis (sebagai pedoman hidup kedua) sebagai standar dalam IPTEK. Standar yang dimaksud tidak melakukan penolakan dan menimbulkan pertentangan antara ilmu dan Al-Qurean.

2. Syariah Islam sebagai standar pemanfaatan IPTEK Standar syariah yang diberikan untuk memanfaatkan IPTEK adalah mengenai halal haram. IPTEK yang diperbolehkan untuk dimanfaatkan adalah Iptek yang telah dihalalkan syariah. Sedangkan Iptek tidak boleh dimanfaatkan apabila diharamkan oleh syariah. ${ }^{26}$

\footnotetext{
${ }^{24}$ Saefudin Zuhri, Jurnal Pendidikan Agama Islam, p-ISSN: 2407-4616 e-ISSN: 2654-3575, Vol.7, No.1, Januari-Juni 2020, hal. 80

25 Ibid, hal. 81

${ }^{26}$ Akhmad Syahri, Spirit Islam, hal. 56
} 
Islam berperan untuk mengisi nilai tentang metode atau cara bagaimana teknologi pendidikan dapat berlangsung dengan baik, baik di lembaga formal, informal, maupun nonformal dalam semangat perkembangan teknologi pendidikan. Saat ini seyogyanya Islam menjadi standarisasi ilmu pengetahuan, karena Islam berdasarkan pada pemilik segala ilmu yang ilmu-Nya mencakup segala sesuatu.. Proses Islamisasi IPTEK mengakibatkan disiplin ilmu dapat berubah menjadi jalur dakwah yang efisien dan efektif. Hal yang sudah diketahui bahwa Islam mengajarkan adanya landasan dogmatika yang disebut "rukun Iman dan rukun Islam". Namun sangat disayangkan dalam rentang waktu kini rukun Iman dan rukun Islam tidak dimengerti sebagai landasan kebenaran yang ada karena benar dengan sendirinya. Bagaimanapun juga IPTEK adalah hasil kerja pikiran manusia yang dilakukan dengan menggunakan akal spekulatif (rasional, logis) dan akan empiris dengan memanfaatkan pengalaman rasional atau teknis. Objeknya berupa data verbal yang oleh Islam dikenal dengan AlQurean dan As Sunah. Tanpa mengubah keyakinan bahwa kebenaran Al-Qurean bersifat mutlak dan abadi, ilmu yang dibangun dari tafsir atas ayat-ayat Al-Quran adalah hasil kerja pikiran di dalam ruang-waktu yang relative berubah dan berkembang. ${ }^{27}$

Pendidikan Islam mengajarkan bahwa globalisasi mendorong manusia khususnya umat beragama untuk mampu menangkap peluang dan menghadapi tantangan pada era 4.0 ini. Hal ini karena permasalahan pembangunan peradaban bukan dari ajaran agama melainkan manusianya. Sebagai contoh, umat Islam pernah memiliki peradaban modern yang ditandai dengan adanya perpustakaan Bait al-Hikmah yang memproduksi pengetahuan. Dengan potensi ilmu yang dianugerahkan Allah bersama penundukan yang dilakukan-Nya, manusia mampu meraih dengan mudah segala sesuatu yang terbentang di alam raya melalui keahlian di bidang teknik, atau dengan kata lain, teknilogi dan alat-alat yang dihasilkannya.

Pendidikan Islam justru mendukung pengembangan ilmu dan teknologi. Era industri 4.0 tidak perlu dianggap ancaman bagi agama, sebaliknya agama bukanlah ancaman terhadap revolusi industri 4.0. Dalam kaitan ini perlu ditekankan pentingnya mengharmoniskan ilmu pengetahuan dan teknologi (Iptek) dengan agama. Iptek harus selalu dilandasi oleh nilai-nilai moral-agama agar tidak bertolak belakang terhadap nilai-nilai kemanusiaan. Sedangkan ajaran

\footnotetext{
${ }^{27}$ Mulkhan, Abdul Munir S.U. Nalar Spiritual Pendidikan, hal. 234
} 
Islam harus didekatkan dengan konteks modernitas, sehingga dapat bersifat kompatibel dengan segala waktu dan tempat. ${ }^{28}$

Era industri 4.0 ditandai dengan dua situasi yang sangat berat:

1. Industri akan lebih banyak mengandalkan komputer dan robot, sehingga tenaga manusia akan dikurangi secara radikal. Dengan demikian, lapangan pekerjaan alumni sekolah dan universitas, akan menghadapi kesulitan besar untuk mendapatkan pekerjaan.

2. Akan tetapi era cyber juga mendatangkan manfaat besar jika bisa dioptimalkan seluruh peluangnya. Oleh sebab itu, era ini juga sering disebut sebagai era disruptive innovation (inovasi yang mengganggu pemain utama). Inovasi ini terbuka bagi siapa saja, karena setiap orang menjadi boss untuk dirinya sendiri, umtuk ide dan cita-citanya sendiri. Tagihan untuk sukses di era industri 4.0 adalah:

a) Harus menjadi anak bangsa yang kreatif, agar mereka bisa menjadi sangat mandiri.

b) Harus menjadi anak bangsa yang inovatif, agar sukses dalam usaha berbasis kreatifitasnya sendiri.

c) Harus menjadi anak bangsa yang inklusif, yang bisa berkolaborasi lintas etnik, budaya, dan agama, sehingga pandangan dunianya tidak sempit, tapi setidaknya ASEAN sebagai singel market bisa mereka optimalkan.

Prof. Dede Rosyada (dalam jurnal Saefudin Zuhri), Secara teoritik, kreatifitas dan inovasi tidak ada mata pelajaran atau mata kuliahnya. Oleh sebab itu, kini kedua skill tersebut dititipkan pada proses pedagogi. Untuk itulah Indonesia beralih dari aliran behaviorisme kepada konstruktivisme, dalam upaya memaksimalkan hasil pendidikan agar menghasilkan manusia Indonesia yang cerdas, kreatif dan inovatif. Sementara inklusivisme merupakan pokok bahasan yang sudah sejak lama ada dalam materi bahan ajar para siswa.

Berdasarkan uraian ini, reorientasi kurikulum PAI meniscayakan bahwa keluaran PAI di sekolah, yang harus dikembangkan, dibimbing dan dibelajarkan oleh para guru alumni jurusan program studi PAI adalah:

\footnotetext{
${ }^{28}$ Talitha Kenzia, 2019, kompasiana. com
} 
1. Memiliki kompetensi dan memiliki komitmen dalam keimanan.

2. Memiliki kompetensi dan mengimplementasikan ketaqwaan.

3. Memiliki kompetensi dan mengimplementasikan toleransi.

4. Memiliki kompetensi untuk mengintegrasikan spirit agama pada prilaku profesi, sosial dan personal..

5. Memiliki sikap dan pandangan terbuka, agar bisa kerjasama lintas budaya, etnik, dan agama.

6. Menjadi orang-orang kreatif, agar bisa lebih mandiri dalam pengembangan. Kehidupan lewat partnershi dalam bisnis dengan seluruh bangsa ASEAN.

7. Menjadi orang-orang inovatif, agar menghasilkan sesuatu yang orang-orang di dunia membutuhkan hasil karyanya. ${ }^{29}$

Menurut JP Guilford (dalam Saefudin Zuhri) seseorang yang kreatif akan memiliki ciriciri sebagai berikut:

1. Flexibility, yakni memiliki kemampuan keluar dari tradisi dan kebiasaan, untuk mendapatkan ide baru, kebedaan dan hasil-hasil yang tidak biasa.

2. Fluency, memiliki kamampuan untuk berfikir banyak ide, dan banyak alternatif penyelesaian problem.

3. Elaboration, memiliki kemampuan untuk bekerja detail dari setiap ide dan solusi.

4. Tolerance and ambiguity, memiliki kemampuan untuk merekonsiliasi berbagai ide yang bertentangan satu sama lain, tanpa melahirkan ketegangan baru.

5. Originality, memiliki kemampuan melahirkan ide-ide, pemikiran, model, yang benar-benar baru, berbeda dengan yang lain, dan mampu melahirkan sesuatu yang benar-benar di luar yang sudah ada.

6. Sensitivity, memiliki kepekaan terhadap permasalahan yang muncul di lingkungannya.

${ }^{29}$ Ibid, hal. 82

35 I P a g e 
7. Curiosity, memiliki sikap terbuka terhadap masukan-masukan baru, informasi-informasi baru, dan memiliki keinginan kuat untuk menggunakan berbagai informasi yang dimilikinya itu untuk menyelesaikan permasalahan yang dihadapinya.

8. Independence, memiliki kemampuan untuk berfikir dan memikirkan permasalahan dengan kemampuannya sendiri.

9. Action, memiliki kemampuan untuk mewujudkan ide-idenya menjadi kenyataan, dengan antusias dan energetik.

10. Commitment, memiliki komitmen dan kepedulian yang tinggi untuk menyelesaikan permasalahan dengan ide dan cara-cara baru. ${ }^{30}$

Kreatif dan inovatif itu tidak ada pelajaran atau mata kuliahnya, sehingga sekolah harus ada ilmu dan skill, pendidikan harus melahirkan orang-orang kreatif, skill dititipkan pada proses pedagogig dan mendorong kreatifitas anak. Anak harus mempunyai imajinasi dengan cara memberikan tantangan agar bisa berimajinasi.

Pendidikan agama Islam harus menurunkan idealisme yang bisa mencetak peserta didik komitmen beragama, profesional tetapi komitmen dengan agama, tidak membatasi diri, lebih banyak integratif, berbisnis tidak hanya dengan sesama muslim tetapi juga dengan non muslim.

\section{Penutup}

pendidikan memiliki keterkaitan erat dengan globalisasi yang kemudian melahirkan revolusi industri 4.0. Pendidikan tidak mungkin menisbikan proses globalisasi yang akan mewujudkan masyarakat global ini. Dalam menuju era globalisasi, Indonesia harus melakukan reformasi dalam proses pendidikan, dengan tekanan menciptakan sistem pendidikan yang lebih komprehensif, dan fleksibel, sehingga para lulusan dapat berfungsi secara efektif dalam kehidupan masyarakat global demokratis. Untuk itu, pendidikan harus dirancang sedemikian rupa yang memungkinkan para peserta didik mengembangkan potensi yang dimiliki secara alami dan kreatif dalam suasana penuh kebebasan, kebersamaan, dan tanggung jawab. Di samping itu, pendidikan

\footnotetext{
${ }^{30}$ Ibid, hal. 83
} 
harus menghasilkan lulusan yang dapat memahami masyarakatnya dengan segala faktor yang dapat mendukung mencapai sukses ataupun penghalang yang menyebabkan kegagalan dalam kehidupan bermasyarakat. Salah satu alternatif yang dapat dilakukan adalah mengembangkan pendidikan yang berwawasan global. ${ }^{31}$ Yaitu dengan pemanfaatan teknologi pendidikan. Selain itu, program pendidikan harus diperbaharui, dibangun kembali atau dimoderenisasi sehingga dapat memenuhi harapan dan fungsi yang dipikulkan kepadanya. Sedangkan solusi pokok menurut Rahman adalah pengembangan wawasan intelektual yang kreatif dan dinamis dalam sinaran dan terintegrasi dengan Islam harus segera dipercepat prosesnya. Sementara itu, menurut Tibi, solusi pokoknya adalah secularization, yaitu industrialisasi sebuah masyarakat yang berarti diferensiasi fungsional dari struktur sosial dan sistem keagamaannya. ${ }^{32}$ Berbagai macam tantangan tersebut menuntut para penglola lembaga pendidikan, terutama lembaga pendidikan Islam untuk melakukan nazhar atau perenungan dan penelitian kembali apa yang harus diperbuat dalam mengantisipasi tantangan tersebut, model-model pendidikan Islam seperti apa yang perlu ditawarkan di masa depan, yang sekiranya mampu mencegah dan atau mengatasi tantangan tersebut.

\footnotetext{
${ }^{31}$ Zamroni, 2000, Paradigma Pendidikan Masa Depan, Jogjakarta, Gigraf Publishing, hal. 90-91

${ }^{32}$ Wahid Abdul, 2008, Isu-isu Kontemporer Pendidikan Islam, Semarang, Need's Press, hal. 28
} 


\section{DAFTAR PUSTAKA}

Arif, Khusnan, Teknologi Pembelajaran Pai (Pendidikan Agama Islam) dalam Paradigma Konstruktivisme, Jurnal Fikroh, Vol.4, No. 2, Januari 2011

Arifin, H.M, 2014, Ilmu Pendidikan Islam, Jakarta, Bumi Aksara, cet. Ke-6

Asnawan, Pendidikan Islam dan Teknologi Komunikasi, Jurnal Falasifa, Vol. 1, No. 2 , September 2010

Fajar, Malik, Holistik Pemikiran Pendidikan, Jakarta, Raja Grafindo Persada, 2005, hal. 131

Hidayat, Nur, Peran dan Tantangan Pendidikan Agama Islam Di Era Global, Jurnal elTarbawi, Volume XIII, No 2, 2015, hal.135-137

https://www.zenius.net/blog.revolusi industri https://uin-malang.ac.id/r/181101/jangan-tinggalkan-nilai-islam-di era-industri 4.0 https://www.viva.co.id>vstory

Indianto, Dimas, Pendidikan Agama Islam Dalam Revolusi Industri 4.0, digital.library. Ump.ac.id/254/4/9

Iswan dan Herwina, Penguatan Pendidikan Karakter Perspektif Islam dalam Era Millenial IR 4.0, Prosiding Seminar Nasional Pendidikan Era Revolusi "Membangun Sinergitas dalam Penguatan Pendidikan Karakter pada Era IR 4.0" Universitas Muhammadiyah Jakarta, Indonesia, 24 Maret 2018.

Kenzia, Talitha, 2019, kompasiana.com/talithakenzia0995/5dff2a670

Mulkhan, Abdul Munir S.U. (2002), Nalar Spiritual Pendidikan: Solusi Problem Filosofis Pendidikan Islam, Yogyakarta, PT Tiara Wacana 
Pewangi, Mawardi, 2019, Journal.unismuh.ac.id/index.php/tarbawi/article/view/347/320

Priatmoko, Sigit, E-Jurnalunisda.ac.id/index.php/ta'lim/article/view/948/1066, Vol.1, No.2, 2018, hal. 229

Rosyada, Dede, iain-padangsidimpuan.ac.id/prof-dr-dede-rosyadama-jadilah-guru-yangkreatif-dalam-menghadapi-era-industri-4-0/

Rosyid, M Ainur, 2017, Hadits-hadits Tarbawi, Yogyakarta, Diva Press.

Samrin, Pendidikan Islam di Era Globalisasi (Peluang \& Tantangan, Shoutut Tarbiyah, Ed. Ke-36 Th. XXIII, Mei 2017, hal.4-5

Saniah, 2019, qureta.com/post/pendidikan-islam-dan-revolusi-industri-4-0-1

Shaleh, Abdul Rachman, 2005, Pendidikan Agama \& Membangun Watak Bangsa Jakarta, PT RajaGrafindo Persada.

Syahri, Akhmad, Spirit Islam dalam Teknologi Pendidikan Di Era Revormasi Industri 4.0, Attarbiyah, Volume 28, 2018

Syakur, Abdus, Revitalisasi Teknologi Pendidikan Islam, Tadris Volume 11 Nomor 2, Suwardana, Hendra, Revolusi Industri 4.0 Berbasis Revolusi Mental, JATI UNIK Vol.1, No.2, 2017, hal. 102 Desember 2016

Tidjani, Aisyah, Manajemen Lembaga Pendidikan Islam Menghadapi Tantangan Globalisasi, Jurnal Reflektika, Vol. 13, No.1, Januari-Juni 2017

Wahid, Abdul, 2008, Isu-isu kontemporer Pendidikan Islam, Semarang, Need's Press Zamroni, 2000, Paradigma Pendidikan Masa Depan, Jogjakarta, Gigraf Publishing Zuhri, Saefudin, Manajemen Pembelajaran Agama dan Keagamaan di Era Industri 4.0, Jurnal Pendidikan Agama Islam p-ISSN: 2407-4616 e-ISSN: 2654-3575, Vol.7, 
No.1, Januari-Juni 2020 